\title{
Fesyen Akademik sebagai Alternatif Kebaruan dalam Budaya Populer
}

\author{
Lois Denissa \\ Program Studi DIII Seni Rupa dan Desain, Fakultas Seni Rupa dan Desain, \\ Universitas Kristen Maranatha \\ Jalan Prof. drg. Surya Sumantri 65, Bandung \\ Email: lois_denissa@yahoo.co.id
}

\begin{abstract}
Fashion is not only to protect the body from weather, disease, or for neatness and politeness reasons. It is also a medium for communication that expresses taste, attitude, gender, identity, trend, ethnicity, social class, and culture. This research uses a descriptive analysis method to expand the communicative function of fashion. In this case, mass media has become an industrial agent to persuade modern women, both in the city and region. Women tend to be enamoured with the ads in order to make their appearance up to date and to idealise their body as shown in the advertising. Advertising models are always displayed with beautiful, charming, and highlighted the sensual body. This reaserch found that academic fashion that puts research and creativity as the basis of its work has countered the idea of fashion advertising. Academic fashion contributes to give popular culture different meanings by creating innovation that inspires modern women with multi-layered messages.
\end{abstract}

Keywords: academic fashion, communication, multi-layered message, popular culture

\begin{abstract}
ABSTRAK
Fesyen sebagai busana tidak hanya berperan sebagai pelindung tubuh atas gangguan cuaca dan penyakit, atau untuk alasan kerapian dan kesopanan. Fesyen juga merupakan media komunikasi yang mengungkapkan selera, sikap, gender, identitas, tren, etnisitas, kelas sosial, dan budaya. Penelitian ini menggunakan metode diskriptif analisis untuk mengungkap fungsi komunikatif fesyen. Dalam hal ini, media massa telah menjadi agen industri dalam membujuk perempuan modern, baik di kota maupun di daerah. Perempuan cenderung terpikat mengikuti arus iklan agar dapat selalu tampil up to date dan menggemari pemujaan akan tubuh yang ideal, layaknya perempuan dalam iklan. Model iklan selalu disiasati dengan paras cantik, menawan, dan menonjolkan tubuh yang sensual. Penelitian ini menemukan bahwa fesyen akademik yang menempatkan penelitian dan kreativitas sebagai basis dalam berkarya menjadi alternatif terhadap kecenderungan fesyen iklan. Fesyen akademik ikut mengisi budaya populer dengan menciptakan kebaruan yang mampu menginspirasi perempuan modern dengan pesan yang berlapis.
\end{abstract}

Kata kunci: budaya populer, fesyen akademik, komunikasi, pesan berlapis 


\section{PENDAHULUAN}

Sebagian besar masyarakat telah memahami bahwa fesyen memiliki kekuatan retoris untuk berkomunikasi. Kekuatan fungsi komunikatif fesyen dalam busana telah dimanfaatkan, baik oleh individu, media massa, maupun industri. Tampilan fesyen digunakan untuk peningkatan identitas diri, tidak hanya perempuan namun juga laki-laki. Fungsi fesyen digunakan untuk mencari keuntungan bagi pemilik modal. Bagai gayung bersambut, media yang bekerja untuk kepentingan industri telah berhasil pula menghipnotis kaum perempuan dengan tampilan mode yang terus berganti tanpa henti. Pernyataan bahwa fesyen sebagai seni yang persuasif seperti yang dinyatakan Malcom Barnard terbukti benar adanya (1996: 178).

Media massa dan fashion show yang gencar menyajikan mode populer kekinian, dalam putaran waktu yang cepat tengah menjadi tren budaya yang terus dicari masyarakat modern. Media ini mencakup berbagai bentuk iklan, seperti siaran televisi, tabloid, majalah, koran, billboard, megatron, dan sebagainya. Fashion show terus beroperasi dari skala besar hingga kecil, dari festival model Indonesia Fashion Week/IFW, Jakarta Fashion, Food and Festival/JF3, yang bertempat di ibukota provinsi hingga festival mini di sebuah ruangan pada pusat perbelanjaan, acara perayaan sekolah, dan kantor-kantor daerah. Kecenderungan untuk tampil modis mengikuti model dalam iklan-iklan media, kini telah menjadi gaya hidup sebagian besar perempuan Indonesia, tidak hanya di kota-kota besar tapi juga di pelosok-pelosok daerah (Wardhani, 2016: 338).

Kemajuan teknologi informasi, seperti pada tayangan televisi, situs internet Youtube, dan Instagram yang mudah diakses di segala tempat dan waktu, menjadi pemicu yang mempercepat dan memperluas tercapainya gaya berbusana seperti yang dipromosikan media. Tampilan fesyen yang disajikan iklan menjadi hidangan yang menggoda untuk segera dikonsumsi dan memuaskan konsumen. Mengikuti gaya fesyen dalam iklan akan mengangkat dan menaikkan citra diri, selalu tampil up to date, mengikuti tren yang membuat sebagian besar masyarakat perempuan dinilai dinamis dan tampak modern.

Fesyen busana, bukan sekedar tampilan busana dan asesoris yang melekat pada tubuh, tetapi telah berkembang menjadi gaya hidup 'baru', yaitu tampil cantik sempurna sepanjang waktu, seperti imaji perempuan berwajah komersial dalam iklan (Sunindyo dalam Ibrahim, 2011: 65). Citra perempuan dalam iklan pada umumnya dipilih yang ideal, berparas cantik, putih, muda, ramping, dan memiliki daya pikat sensual yang menggoda. Citraan perempuan yang tak henti dipentaskan dalam iklan ini, kemudian membentuk stereotip bahwa untuk menjadi perempuan sempurna dapat dengan mudah diraih, dan bukan sekedar impian, bilamana konsumen mau mengikuti bujuk rayu iklan dengan membeli produknya. Penanaman stereotip ini tak lain adalah propaganda komoditas formasi kapitalistik yang berujung pada pencarian akan keuntungan pemilik modal belaka, dan media menjadi agen yang ampuh.

Gencarnya bujuk rayu media ini terus menerus dikonstruksi menjadi budaya populer. Iklan fesyen telah menjadi konsumsi massal perempuan modern dalam dua dekade terakhir. Di manapun kita berada, iklan tentang fesyen menjadi panorama yang mengikuti visual kita. Di rumah ada pada layar monitor, ketika kita ke luar rumah ada tertampang di kiri kanan jalan, di kantor, di restoran, di mall, di toko-toko perbelanjaan di ruang publik terbuka, bahkan di pasar tradisional. Iklan fesyen menjajakan visualnya dan menjadi budaya populer yang terus ditemukan di ruang-ruang hidup manusia, menjadi budaya sandang 
siap pakai yang menawarkan citra perempuan, dan juga laki-laki modern. Pada kondisi yang serupa, pihak industri fesyen, produk kecantikan wajah, hairdo, asesoris, tas dan sepatu, jasa kecantikan mendefinisikan bagaimana berpenampilan menarik. Pada kondisi ini, fesyen akademik kian bermunculan bersamaan dengan budaya penampilan diri yang telah bergeser kepada pemujaan tubuh/fetishism of body (Ibrahim, 2011: 57). Fesyen akademik adalah jenis fesyen yang dihasilkan dari proses belajar di perguruan tinggi, tempat kreativitas mahasiswa diasah melalui studi literatur, studi image, proses bimbingan, dan diskusi.

Walaupun dalam merancang busana, dunia fesyen akademik lebih memokuskan pada perkembangan kreativitas mahasiswa didik, namun tak dapat dipungkiri bahwa dalam praktiknya, tetap fokus pada bagaimana menonjolkan citra perempuan yang menawan dengan tampilan busana yang modis. Mau tidak mau, fesyen akademik dengan misi entrepreneurship, dalam perjalanannya akan bersinggungan pula dengan media massa. Seperti dalam pembuatan leaflet, poster, iklan di radio, koran, dan website institusi, iklan tetap diperlukan untuk meningkatkan promosi dan mengundang apresiasi masyarakat luas.

Fashion show di ruang auditorium menjadi sebuah keniscayaan, artificial lighting dan musik yang hingar bingar menjadi tuntutan selera mahasiswa didik sebagai sesuatu yang tidak dapat dihindarkan. Fashion show dinilai menjadi puncak ekspresi dan promosi capaian mahasiswa didik yang membutuhkan pengakuan khalayak luas. Citra ideal yang dikonstruksi oleh fesyen akademik diharapkan tidak sama seperti citra kecantikan perempuan komersial yang ditawarkan media massa dalam iklan. Nilai-nilai kreativitas yang dihasilkan mahasiswa dapat menjadi khasanah yang melawan perburuan perempuan modern pada iklan komersial.
Sebaliknya, fesyen akademik menawarkan kepada perempuan Indonesia, untuk mengembangkan kreativitasnya dan mengangkat nilai-nilai luhur budaya bangsa dengan berbusana modis, sopan, disertai dengan kebaruan nilai estetika yang bermuatan nilai-nilai akademik, serta memiliki kekayaan kesan dan pesan. Kekayaan kreativitas mahasiswa dalam mengekspresikan ide terus digali agar mampu menghasilkan kreasi segar yang menginspirasi perempuan modern. Agar mereka tidak terjebak dalam perburuan konsumtif yang hanya menguntungkan pihak kapitalis. Inspirasi kreatif yang dihasilkan mahasiswa dapat memberi alternatif fesyen yang inovatif dengan makna dan pesan yang berlapis-lapis.

\section{METODE}

Penelitian ini dilakukan dengan metode deskriptif analitis terhadap fenomena fesyen yang terjadi pada dekade terakhir. Fenomena ini terjadi pada sebagian besar perempuan modern di berbagai strata sosial, dengan gaya hidup yang sangat dipengaruhi oleh tampilan mode pada iklan komersial. Putaran mode mulai dari model sepatu, tas, ikat pinggang, berbagai tipe busana, syal, topi, asesoris, handphone hingga gaya rambut. Fenomena putaran tampilan fesyen ini banyak dijumpai pada iklan media sosial, seperti majalah, tabloid, instagram, televisi, poster, neon box, baligo, megatron dan sebagainya, tersebar di segala ruang dan waktu kehidupan manusia.

Iklan yang bekerja untuk industri fesyen selalu tampil serba memukau mata dengan produk yang menawan dan terus diperbarui dari waktu ke waktu. Perempuan yang dipilih menjadi model untuk promosi produk fesyen pada umumnya memiliki daya pikat komersial. Perempuan komersial cenderung menonjolkan kecantikan dengan gestur tubuh yang mengeksploitasi seksualitas. Perempuan 
yang cantik dengan tubuh sensual terus menerus mengisi budaya visual masyarakat. Kemudian, ia membentuk citraan yang mengarah kepada pemujaan akan tubuh yang ideal memesona (fetishism), yang terus menggoda untuk dilihat dan dicapai oleh semua perempuan.

Perempuan modern di segala tempat ingin tampak menarik; dan perempuan dalam iklan dengan segala yang melekat pada tubuhnya menjadi pendorong bahwa citraan menawan itu, seolah bisa dimiliki bila mengikuti setiap detail dandanannya. Dorongan untuk terus mengkonsumsi fesyen agar up to date, telah memerdaya perempuan modern untuk terus melakukan pemujaan akan tubuh ideal sebagai kebutuhan yang dapat menaikkan identitas diri saat tampil di ruang-ruang publik.

Penelitian ini melakukan analisis dengan cara mengkategorikan visual fesyen komersial yang dijumpai pada iklan. Beberapa image dari iklan fesyen yang mewakili, dan image karya tugas akhir mahasiswa fesyen Program Studi Diploma III Seni Rupa dan Desain, Fakultas Seni Rupa dan Desain, Universitas Kristen Maranatha, menjadi sampel studi kasus penelitian. Sampel dipilih berdasarkan kekuatan visual yang mendukung masing-masing kategori. Metode diskriptif dilaksanakan dengan cara menayangkan perempuan model dengan fesyen yang dilekatkan pada tubuh model dalam iklan, kemudian memberikan analisis secara diskriptif.

Kekuatan komersial yang tervisualkan cenderung mengeksploitasi tubuh perempuan, kemudian mengarah pada pemujaan akan tubuh yang sempurna, yaitu tubuh yang dimiliki perempuan dalam iklan. Pemvisualan yang dikonstruksi kapitalis ini telah menghidupi cita rasa sebagian besar perempuan modern di kota, maupun di daerah. Citra perempuan komersial dalam iklan, seolah-olah adalah citra ideal yang mesti dikejar sebagai identitas satu-satunya. Masyarakat perempuan dikondisikan untuk hidup berlandas pada mekanisme pasar ini (Wardhani, 2016: 349).

Pada tahapan analisis dilakukan perbandingan berbagai visual fesyen yang dipasarkan oleh media massa dengan fesyen hasil karya mahasiswa dari hasil pendidikan akademiknya.

Fesyen akademik melakukan hal yang berbeda, berlandaskan pada fesyen yang memiliki kekuatan besar untuk berkomunikasi dan memengaruhi, seperti pepatah bahasa Latin, "Fesyen is more powerful than any tyrant" (Ibrahim, 2011: xiv).

Mahasiswa dilatih untuk mengomunikasikan ide-ide kreativitasnya melalui karya busana. Ide kreasi busana mahasiswa dilakukan melalui studi literatur, pencarian berbagai isu, fenomena, studi image, penemuan hal baru yang belum banyak terungkap, dan hal apapun yang menarik untuk digali dan perlu untuk disosialisasikan lewat desain busana.

Segala sesuatu yang terkait dengan kehidupan manusia, alam lingkungan, dan semesta dapat menjadi sumber inspirasi yang menantang untuk diolah dan dikomunikasikan melalui fesyen busana. Fesyen busana bukan sekedar kain pembungkus tubuh, untuk melindunginya dari sengatan panas matahari, dinginnya udara luar, dan air hujan yang sifatnya fisikal. Fesyen busana mampu menjadi media komunikasi artifaktual, yaitu media komunikasi nonverbal yang memiliki kekuatan untuk memengaruhi.

Setelah melewati pendidikannya, para mahasiswa lulusan akan menjadi agenagen fesyen yang produktif. Mereka akan terus mengembangkan kreasi-kreasi yang inovatif, bukan sekedar mengeksploitasi seksualitas dan pemujaan akan sensualitas tubuh perempuan. Bahasa fesyen memiliki makna yang sangat luas untuk dikomunikasikan, bahkan mampu menjangkau halhal di luar ranah fesyen itu sendiri. Kreasi busana mahasiswa lulusan diharapkan menjadi alternatif yang melawan fesyen 
komersial. Hasil penjajaran masing-masing obyek visual, antara fesyen komersial dan fesyen akademik akan menjelaskan sejauh mana perbedaan kekuatan fesyen telah menarasikan fenomena budaya populer dengan berbagai kekayaan maknanya.

\section{HASIL DAN PEMBAHASAN}

Fesyen busana sebagai artefak budaya populer merupakan fenomena yang tidak dapat disangkal keberadaannya. Di manapun dan kapanpun, fesyen busana menjadi kebutuhan yang dicari dan dikejar oleh sebagian besar masyarakat, terlebih perempuan, baik di kota maupun di daerah. Bukan hanya di hari-hari raya umat beragama, pesta keluarga, atau perayaan komunitas kawula muda, tetapi juga dihari-hari biasa. Fesyen busana telah menjadi kebutuhan yang mengisi setiap ruang hidup manusia, baik di rumah, di sekolah, di kantor, di pasar maupun di tempat ibadah. Tampil menarik dan trendi di ruang publik telah menjadi kebutuhan yang terus bergulir tanpa henti dan telah menjadi gaya hidup sebagian besar perempuan Indonesia.

Fesyen busana tidak lagi sekedar berfungsi fisik seperti melindungi, menyembunyikan tubuh atau bagian kesopanan bagi tubuh (Barnard, 2011: vii), akan tetapi busana mampu menghadirkan aneka fungsi yang berlapis-lapis. Busana memiliki sejumlah peran dan pesan retoris, baik dalam berbagai bentuk ekstasi komunikasi (ecstasy communication), antara lain pajangan budaya, identitas individu, posisi/status kelompok, ideologi maupun kultur tertentu, sejumlah citra yang diinginkan, strata kelas, peran sosial, dan berbagai isu masa depan nasional maupun transnasional (Baudilard, 1987: 130-131).

\section{Media Massa Pemicu Ampuh bagi Tampilan Fesyen}

Pergeseran selera dan gaya hidup berbusana di Indonesia tampak makin mencolok pada 1-2 dekade terakhir. Berita ten- tang figur desainer yang sedang naik daun pun banyak yang ditayangkan dan diwawancarai di berbagai saluran media televisi maupun majalah. Iklan fesyen, asesoris, kosmetika, parfum, milineris yang serba up to date dipajang mencolok di mall-mall, super market, pasar tradisional, bahkan juga di pinggir-pinggir jalan dan etalase pertokoan. Iklan fesyen dipajang dalam bentuk manekin, neon box, billboard dan megatron dalam ukuran serba besar di tempat-tempat yang dipilih secara strategis agar cepat ditangkap oleh pemirsa. Belum lagi, iklan yang mengisi waktu jeda pada acara televisi maupun pada situs, seperti instagram, youtube, dan bisnis on line shop yang begitu semarak.

Di era globalisasi, media massa dalam bentuk iklan ini berperan besar dalam membentuk budaya citra dan budaya cita rasa (Piliang, 1993). Iklan menawarkan gaya visual yang memikat mata, dan secara perlahan tertanam dalam hati pemirsa akan arti pentingnya tampil memesona di muka publik. Gempuran iklan yang datang dari berbagai arah ini memengaruhi pilihan-pilihan cita rasa yang dibuat, membentuk kesadaran dan mendominasi budaya populer tentang bagaimana menjadi perempuan modern. Semua perempuan ingin tampil cantik, menarik, seksi, dan karenanya perempuan akan dikagumi dan dihargai dalam masyarakat yang mengedepankan komoditas. Seperti dikemukakan oleh Helen Gurley Brown dalam majalah Cosmopolitan (dalam Ibrahim, 2011) berikut ini.

...kita semua senang melihat tubuh yang
indah. Perempuan-perempuan itu sendiri
memang sensual karena mereka memiliki
kecantikan yang istimewa. Mereka mem-
perlihatkan kecantikan mereka sehingga
tubuh mereka yang indah dapat diperhati-
kan dan dihargai (Ibrahim, 2011: 62).

Keinginan ini membuat perempuan perkotaan tidak dapat lepas dari bujuk rayu fesyen dalam iklan. Di sisi lain, iklan berperan mendorong terjadinya percepatan pergantian produk. Mode bukan hanya 
Tabel 1. Busana ready to wear dalam iklan

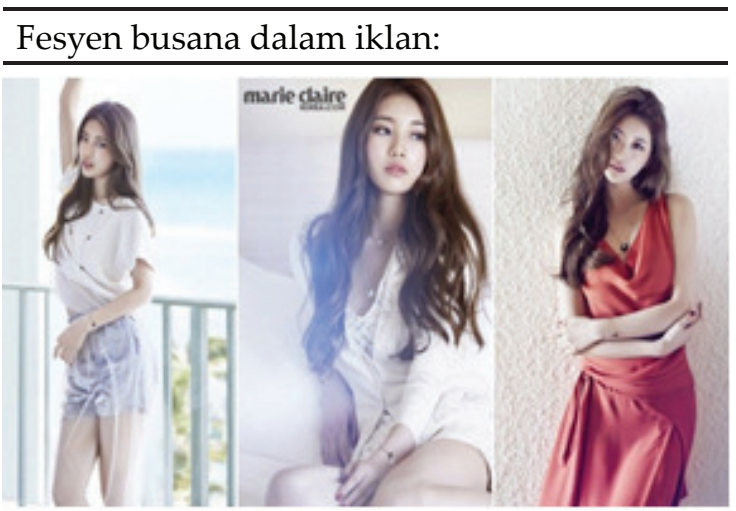

Deskripsi:

Busana ready to wear: denim short pans dengan blouse polos lengan panjang dan two pieces dengan draperry leher yang sangat rendah tanpa lengan, dilekatkan pada perempuan model yang langsing, putih, cantik, rambut tergerai dengan gestur sensual. Model iklan yang serba ideal ini menjadi bujuk rayu industri untuk meningkatkan segmen pasar dengan citraan yang bisa diraih semua perempuan modern apabila mengonsumsi poduk busana yang dipromosikan.

Sumber: https://1.soompi.io/wp content/blogsdir/8/files/2014/07/suzy-800x450.png

tentang busana atau asesoris yang melekat pada tubuh, namun telah menjadi kebutuhan akan gaya hidup sebagian besar masyarakat. Segala materi yang dilekatkan pada tubuh dalam putaran yang terus berganti dilakukan dengan tujuan pemujaan akan tubuh (fetishism). Fetishism pada tubuh kemudian menjadi euphoria baru (Ibrahim, 2011: 62), yaitu mempunyai penggalanpenggalan tubuh, seperti kulit wajah yang selalu bersih tanpa jerawat, rambut tebal hitam bercahaya, pinggang ramping, dada padat berisi, paha dan betis yang putih mulus, ketiak yang selalu segar tanpa rambut seperti pada iklan.

Keseluruhan pesona itu dapat diraih karena kecanggihan teknologi iklan dalam meramu produk industri dengan tampilan yang memikat dan menjanjikan. Produk industri kecantikan dan mode itu disebarkan melalui media yang dikemas begitu menawan dengan paket-paket komoditas yang senantiasa disertai imaji perempuan ideal menurut selera pasar. Adanya dorongan bahwa
Tabel 2. Busana denim dalam iklan

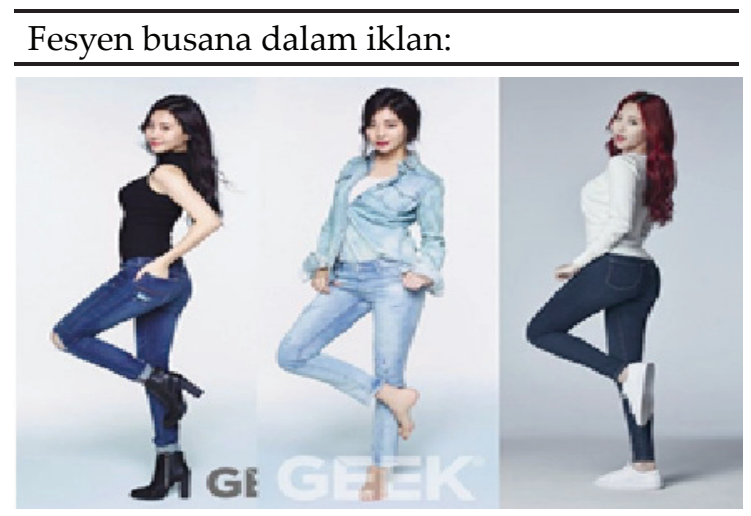

Deskripsi:

Busana ready to wear: denim long pants yang ketat, tank top, kemeja denim yang terbuka dan kaos ketat mitre lengan panjang (base layer) dilekatkan pada perempuan model yang langsing, putih, cantik dengan gestur tubuh sensual. Model iklan yang serba ideal ini menjadi bujuk rayu akan citraan yang bisa diperoleh semua perempuan modern, siapapun, apabila senantiasa mengkonsumsi produk busana yang diiklankan. Visualisasi image menjelaskan gestur tubuh perempuan dieksploitasi guna menonjolkan sensualitas, lebih penting dibanding tampilan produknya. Namun, yang kurang penting itu menjadi kunci untuk meraih citra tubuh yang menggoda itu.

Sumber:https://i.pinimg.com/originals/94/86/db/ 9486dbb874aa47ad122b056a8898197e.jpg

'aku bisa cantik mempesona serupa dengan model dalam iklan' bila senantiasa mengenakan fesyen terkini, produk-produk terbaru, perawatan yang sama, mengikuti latihan kebugaran (body building), seperti opini yang diinjeksikan oleh media.

Keinginan untuk memiliki tubuh sempurna dengan segala yang melekat pada perempuan dalam iklan begitu kokoh karena pencapaian ini akan menaikkan citra tentang dirinya. Hasrat untuk terus mengikuti arus putaran mode yang dikonstruksi oleh industri ini kemudian menjadi kebutuhan yang terus mengalir membentuk sebuah gaya hidup baru. Tampilan tubuh menjadi magnet yang menarik antusiasme perempuan untuk mengikutinya (Yudhistira, 2014: 373). Segala hal yang melekat pada tubuh perempuan di dalam iklan itu, akan berpindah menjadi miliknya bila mengikuti tren yang dipromosikan; tampil menggoda 
Tabel 3. Fetisisme dalam iklan deodoran Rexona

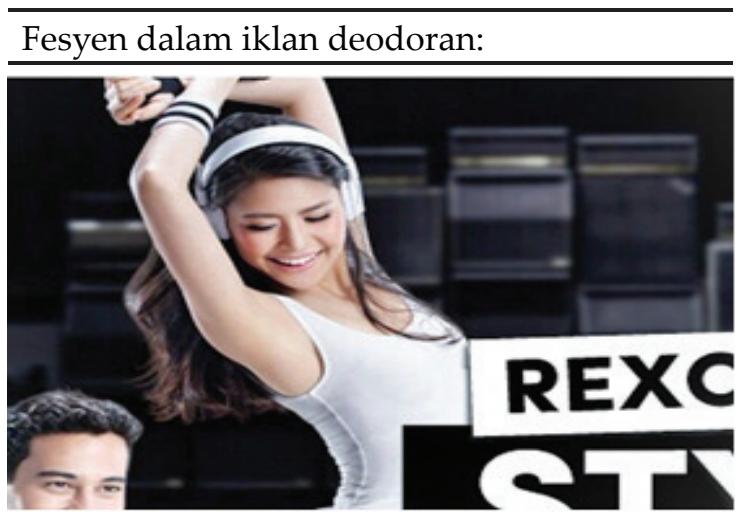

Deskripsi:

Produk deodoran mampu memberikan semua perempuan modern akan tubuh yang bersih tanpa rambut ketiak, keringat dan bau badan yang merintangi dinamika pergaulan. Pemujaan pada tubuh perempuan yang cantik, seksi, harum dan bebas bergerak, seperti perempuan dalam iklan, akan mudah diraih tentunya bila mengonsumsi produk formasi iklan secara rutin (Eco, 1976). Visualisasi image menjelaskan gestur tubuh perempuan dieksploitasi guna menonjolkan sensualitas, postur tubuh perempuan dengan tangan terangkat tampak dominan, lebih utama dibanding fisik produk deodoran Rexona yang justru tidak dihadirkan, hanya diwakili beberapa huruf teks yang tidak selesai.

Sumber:

https://scontent-lga3-1.cdninstagram.com/ vp/ed5feb437b8239947be044d2ae547e4f/ 5BAB9EA8/t51.288515/e15/1029697662083 528002713 1380553800_n.jpg?ig cache key=NzE 1OTMxNTM3NzYxNTc2OTA1.2

secantik, seindah, seputih, seseksi model perempuan-perempuan dalam iklan menjadi target yang pantas dimiliki.

Dalam hal ini, bisa dilihat adanya pertemuan yang sinergis antara ideologi yang dikonstruksi oleh penguasa modal, diskursus media yang gencar mengeksploitasi tubuh perempuan sebagai formasi bujuk rayu, dan penerimaan konsumen perempuan yang cenderung kurang kritis. Konsumen perempuan modern tanpa disadari bak terhipnotis terbawa arus putaran fesyen di media dan menjadikannya sebagai gaya hidup. Ia selalu tergoda mengikuti mode-mode populer agar selalu memperoleh sebutan bergaya keren (stylish). Walau tidak sedikit gaya hidup yang dita- warkan media, dalam banyak hal berganti menjadi kecemasan yang menjerat untuk hidup dalam ilusi dan mimpi. Tampil cantik seperti para bintang ternyata tidak mudah untuk digapai, sebesar apapun upaya untuk terus memburu setiap pergantian iklan yang ada.

Beberapa pemilihan sampling iklan di bawah menjelaskan sejauh mana visualisasi perempuan dalam iklan telah dikonstruksi untuk menonjolkan kecantikan dan sensualitas guna tujuan bujuk rayu. Gestur perempuan dalam iklan telah menarasikan bagaimana sensualitas tubuh perempuan yang tervisualisasikan adalah sasaran yang justru lebih penting daripada segala yang dilekatkan. Fesyen busana yang dilekatkan pada tubuh cenderung hanya menjadi instrumen agar daya tarik tubuh yang sensual itu tampil kuat melebihi promosi iklan busana atau produknya sendiri. Iklan fesyen yang ada semata-mata diformasikan untuk memopulerkan budaya pemujaan akan tubuh perempuan ideal sebagai sebuah pengejaran gaya hidup (Kasiyan, 2008: xxxv). Hal itu seperti tergambar pada tabel 3.

\section{Fesyen Akademik Memperkaya Komunikasi Budaya Populer dengan Pesan Berlapis}

Fesyen akademik, terlebih yang memiliki misi bahwa lulusannya harus mampu mandiri untuk berwirausaha akan mengawali kreativitas berkaryanya melalui penelitian terlebih dahulu. Penelitian yang mengarah pada penggalian ide-ide yang inovatif. Ide dicari dari apa yang mungkin dieksplorasi agar menjadi konsep yang memberi warna kebaruan pada kreasi busana. Apakah itu dari teknik cutting, drapping, pola busana, fabric manipulation atau mengadopsi hal-hal di luar ranah fesyen sebagai konsep berkreasi. Ide yang melatarbelakangi konsep kreasi busana dapat diambil darimanapun. Namun demikian, dalam pengolahannya dapat mengikuti Indonesian Trend Forecasting atau tren internasional sebagai acuan berkreasi. 
Tabel 4. Tubuh perempuan sebagai model fetisisme.

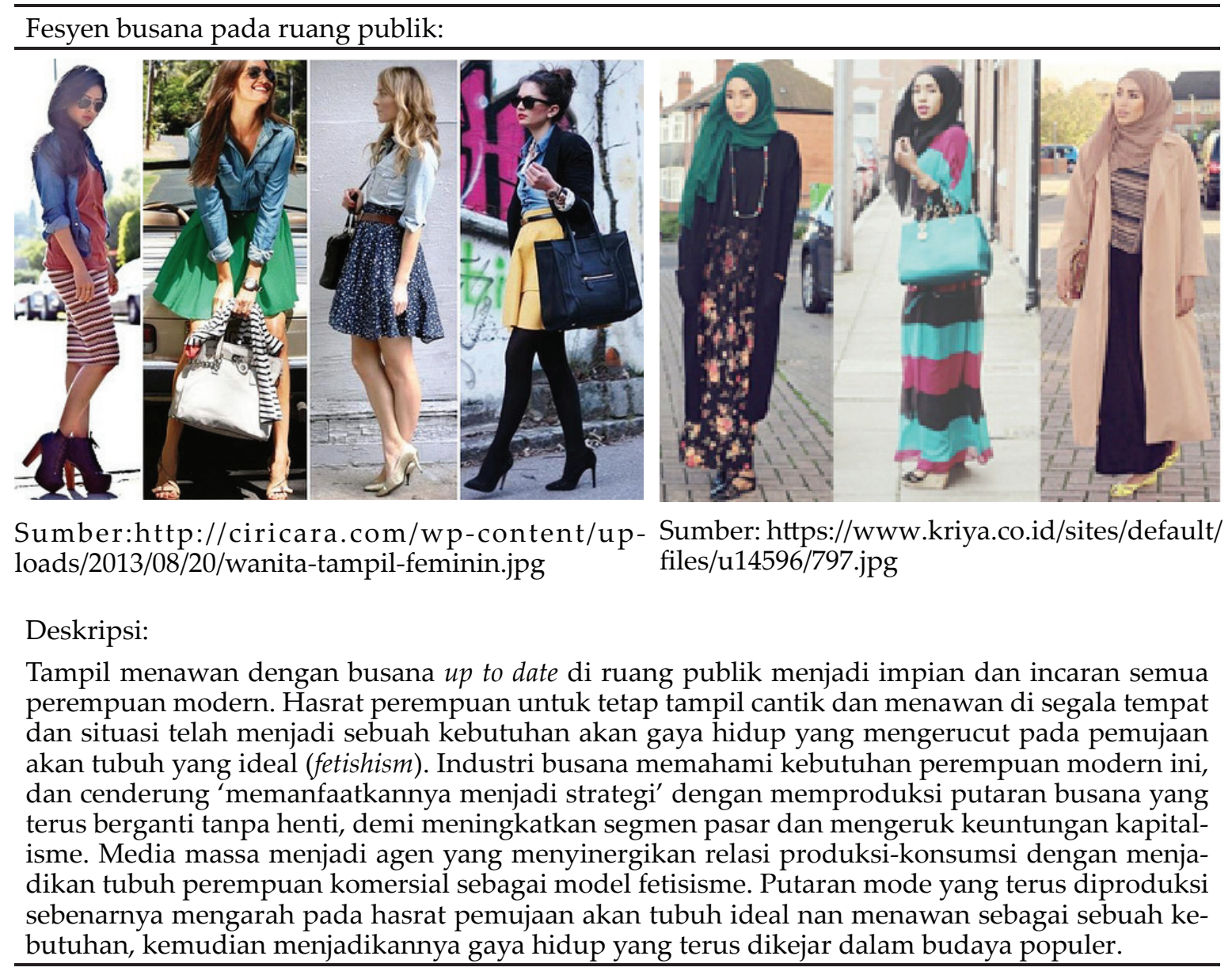

Indonesian Trend Forecasting terbit setiap tahun untuk mengantisipasi arah dan keinginan konsumen terhadap fesyen pada tahun berikutnya. Indonesian Trend Forecasting membuat inovasi-inovasi tren berlandaskan pada kecenderungan akibat berbagai perubahan, seperti demografi, sosial, ekonomi, politik, alam, dan budaya global yang berdampak pada gaya hidup. Dengan memahami perubahan gaya hidup yang terjadi lebih awal, maka akan ada dampak positif berupa peningkatan pasar secara berkelanjutan (Baudrillard, 1998: 25-47). Inovasi-inovasi tren yang dihasilkan Indonesian Trend Forecasting dapat digunakan menjadi dorongan inspirasi bagi insan kreatif, termasuk mahasiswa didik untuk memperkaya proses kreatifnya (Indonesia Trend Forecasting, 2014: 5).

Isu-isu tren yang diinspirasi oleh Indonesian Trend Forecasting pada umumnya mengarah pada kecenderungan masa depan berdasarkan pada fenomena yang ada dan riil terjadi. Apapun dapat diangkat menjadi ide-ide baru yang menarik dalam kreasi fesyen. Perubahan alam, seperti cuaca, gerakan air, kontur tanah, kehidupan laut, hutan, erosi, erupsi, savana, evolusi berbagai tumbuhan langka, sel kanker, dan jamur yang ada dahulu maupun sekarang, dapat diangkat dalam kreasi fesyen populer. Segala teknologi biomics, robotic, joint exposing, hologram, light, perforated, tinker toy, ethnic, layers, subkultur, sejarah, arsitektur, perang nuklir dan dampaknya dapat menjadi konsep kreasi dalam fesyen.

Pada kondisi ini, fesyen menjadi media untuk menyampaikan pesan, peringatan, himbauan, temuan pengetahuan, kritik dan sebagainya secara artifaktual. Dengan mengambil ide berkreasi di luar ranah fesyen pada umumnya atau fesyen konservatif, maka hal 
Tabel 5. Busana 'Lamidexo' inspirasi dari mitologi suku Astec

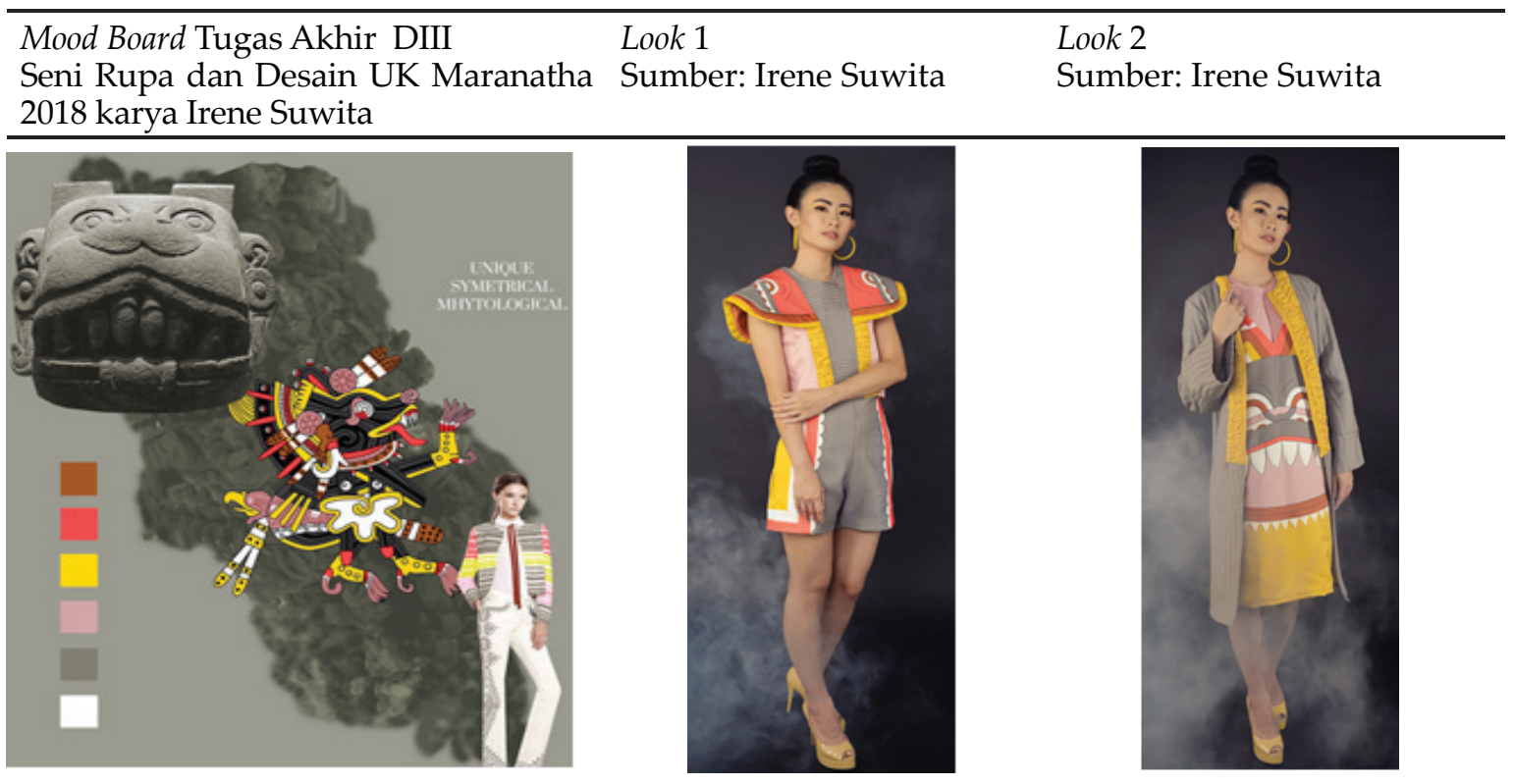

Deskripsi dan analisis:

Busana 'Lamidexo' karya Irene Suwita didasarkan pada hasil penelitian tentang mitologi suku Astec, suku tertua di Amerika Tengah, yang percaya pada kekuatan dewa Xoloth yang mampu melindungi manusia menjelang kematiannya menuju keabadian (afterlife). Dewa Xoloth acapkali kali digambarkan oleh suku Astec sebagai patung berbentuk kepala anjing, yang disebut dewa anjing. Berbagai bentuk kepala anjing ini banyak ditemui di sekitar kuburan. Hiasan dua dimensi berbentuk profil kepala anjing dengan komposisi warna abu, putih, merah, vermilion, cokelat, peach, dan kuning. Busana tradisi suku Astec memiliki garis siluet bentuk busana $H$ line atau lurus tanpa garis pinggang.

Hasil persilangan yang didapat dari studi literatur, studi image tentang artefak patung batu kepala anjing, studi image dewa Xoloth dalam artefak budaya Astec, trend Cryptic subtema Silent creature mountrous dari Trend Grey Zone Forecasting 2017/2018, fabric manipulation, digital color printing on fabric, dan arahan dari dosen pembimbing, menghasilkan empat kreasi busana ready to wear yang unik dan inspiratif. Kreasi busana ini menghasilkan temuan yang inovatif, bukan hanya menjadi busana yang fungsional, namun juga cantik, mampu mengomunikasikan pesan budaya tentang mitologi suku Astec yang semakin punah dan melawan budaya fesyen komersial yang kian mengarah ke pemujaan tubuh.

itu telah membuat peran fesyen sebagai media komunikasi menjadi semakin meluas. Fesyen yang dikenakan pada tubuh perempuan dan laki-laki di ruang-ruang publik menjadi iklan yang berjalan dan turut mempromosikan pesan-pesan yang dilekatkan pada fesyen yang digunakannya. Tubuh dan fesyen kemudian menjadi media yang dapat digunakan menjadi muatan untuk meluncurkan pesan, citra, dan ideologi tentang berbagai fenomena populer.

Sekarang, media tidak terbatas pada papan billboard, manekin, poster, instagram atau di televisi dan youtube yang dapat bergerak secara faktual, artinya sebatas citra yang virtual, namun media dalam tubuh yang nyata dan penuh dinamika, karena dapat tampil menarik seperti para bintang dalam iklan, hasil polesan industri komersial. Tubuh dengan berbagai fesyen yang up to date ini bak model yang melenggang di catwalk ruang-ruang publik memparadekan budaya populer dengan pesan yang berlapis-lapis. Mahasiswa, pada sisi yang lain, mengawali kreasi fesyennya melalui penelitian dengan menggali berbagai ide dari berbagai hal di sekelilingnya, seperti isu masa depan, fenomena yang sedang terjadi, sejarah, sosial, budaya, dan tren yang ada di sekitar kehidupan manusia dan lingkungannya. 
Tabel 6. Busana 'Chandramawa' inspirasi dari ilusi optik garis hitam-putih

\begin{tabular}{lll}
\hline Mood Board Tugas Akhir DIII & Look 1 & Look 2 \\
$\begin{array}{l}\text { Seni Rupa dan Desain UK Maranatha } \\
2018 \text { karya Nicha Lolla Sanjaya }\end{array}$ & Sumber: Nicha Lolla Sanjaya & Sumber: Nicha Lolla Sanjaya \\
\hline
\end{tabular}
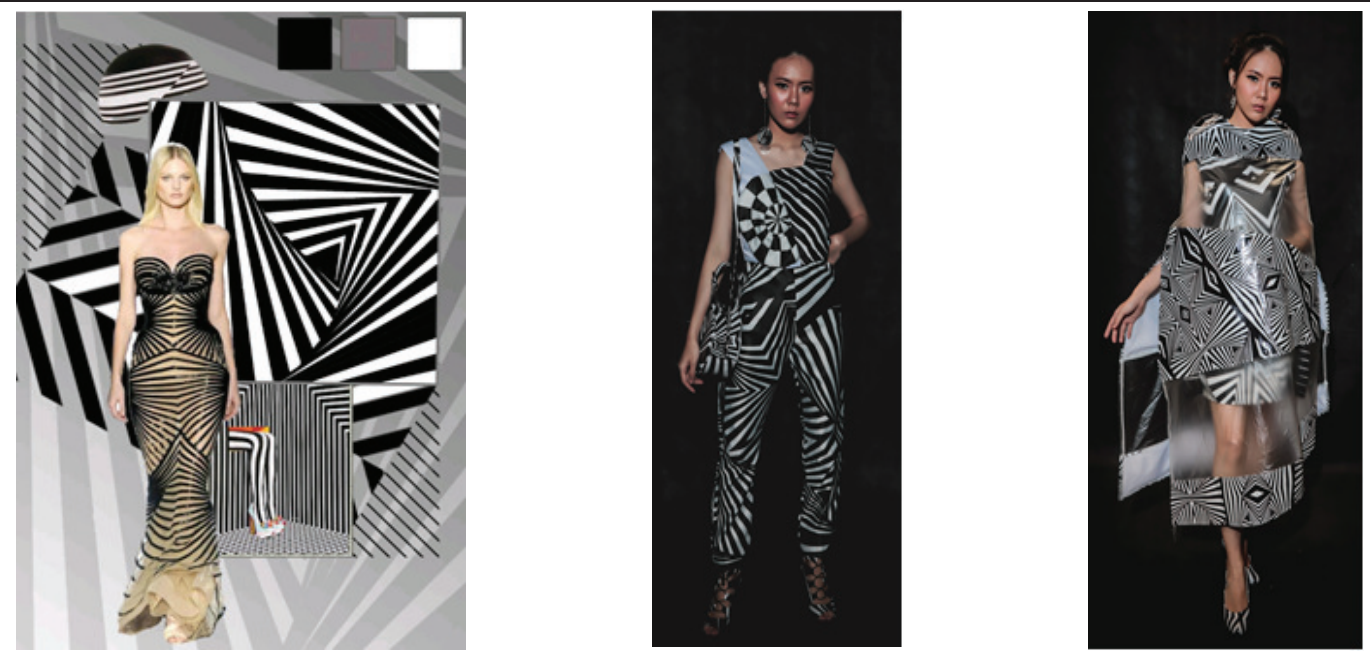

Deskripsi dan analisis:

Busana 'Chandramawa' karya Nicha Lolla Sanjaya didasarkan pada hasil penelitian tentang terbentuknya ilusi optik yang terjadi pada komposisi garis hitam dan garis putih yang diatur secara berselang-seling. Pergeseran dimensi, pola susunan, arah dan ritme pada garis hitam dan garis putih dikomposisikan sedemikian rupa sehingga menimbulkan efek ilusi visual tertentu. Komposisi hitam putih yang terjadi mampu menciptakan dimensi ruang yang dinamis, menarik, dan tidak terduga, walau realitas sesungguhnya berasal dari susunan garis-garis berbentuk dua dimensional. Efek visual ini semakin kaya kesan tiga dimensinya bila dikomposisikan dengan bidang-bidang bernuansa transparan.

Hasil persilangan yang didapat dari studi literatur, studi image tentang ilusi optik yang tercipta akibat permainan garis hitam dan putih, trend Digitariant subtema Optical Transparant dari Trend Grey Zone Forecasting 2017/2018, fabric manipulation, white-black digital printing on leather, dan arahan dari dosen pembimbing, menghasilkan empat kreasi busana ready to wear yang unik dan inspiratif. Kreasi busana ini menghasilkan temuan yang inovatif, bukan hanya menjadi busana yang fungsional, tapi juga dinamis mampu mengomunikasikan kekayaan pengetahuan ilusi optik menjadi inovasi busana, dan melawan budaya fesyen komersial yang kian mengarah ke pemujaan akan tubuh.

Kreasi fesyen yang dihasilkan mahasiswa adalah hasil penelitian yang dikomunikasikan, baik berupa ideologi, maupun yang dituangkan dalam bentuk praktik, seperti hasil reka tekstil, pecah pola, bentuk jahitan (sewing), bentuk potongan (cutting), bentuk balutan (drapping), hingga eksplorasi berbagai teknik seperti eco green, tie dye, pulling fiber, accordion pleat skirt, marbling, fabric painting maupun dalam berbagai pemilihan material. Hasil kreasi mahasiswa fesyen pada gilirannya memerlukan sarana untuk mengkomunikasikan karya ciptaannya kepada masyarakat. Cara yang ditempuh adalah dengan melakukan pameran dalam bentuk bazar dan fashion show di ruang terbuka yang bebas diakses pada acara pameran dan di ruang panggung auditorium yang tertutup dengan menggunakan tiket undangan, yang umumnya dilakukan pada malam hari.

Pada acara pameran, bazar dan fashion show yang rutin dilakukan tiap tahun ajaran. Puncak kreasi dan ekspresi hasil penelitian ini digelar sebagai bentuk komunikasi kepada masyarakat. Beraneka ragam komunikasi dieksplorasi ke ranah nonfesyen, kemudian dipromosikan sebagai fesyen busana yang kemudian menjadi budaya populer. Hal itu tampak pada hasil kreasi, seperti pada table 4-9. 
Tabel 7. Busana 'Antrachoda' inspirasi dari larva pemakan mikroplastik di laut

\begin{tabular}{lll}
\hline Mood Board Tugas Akhir DIII & Look 1 & Look 2 \\
$\begin{array}{l}\text { Seni Rupa dan Desain UK Maranatha } \\
2018 \text { karya Vallerie Janicia }\end{array}$ & Sumber: Vallerie Janicia & Sumber: Vallerie Janicia \\
\hline
\end{tabular}
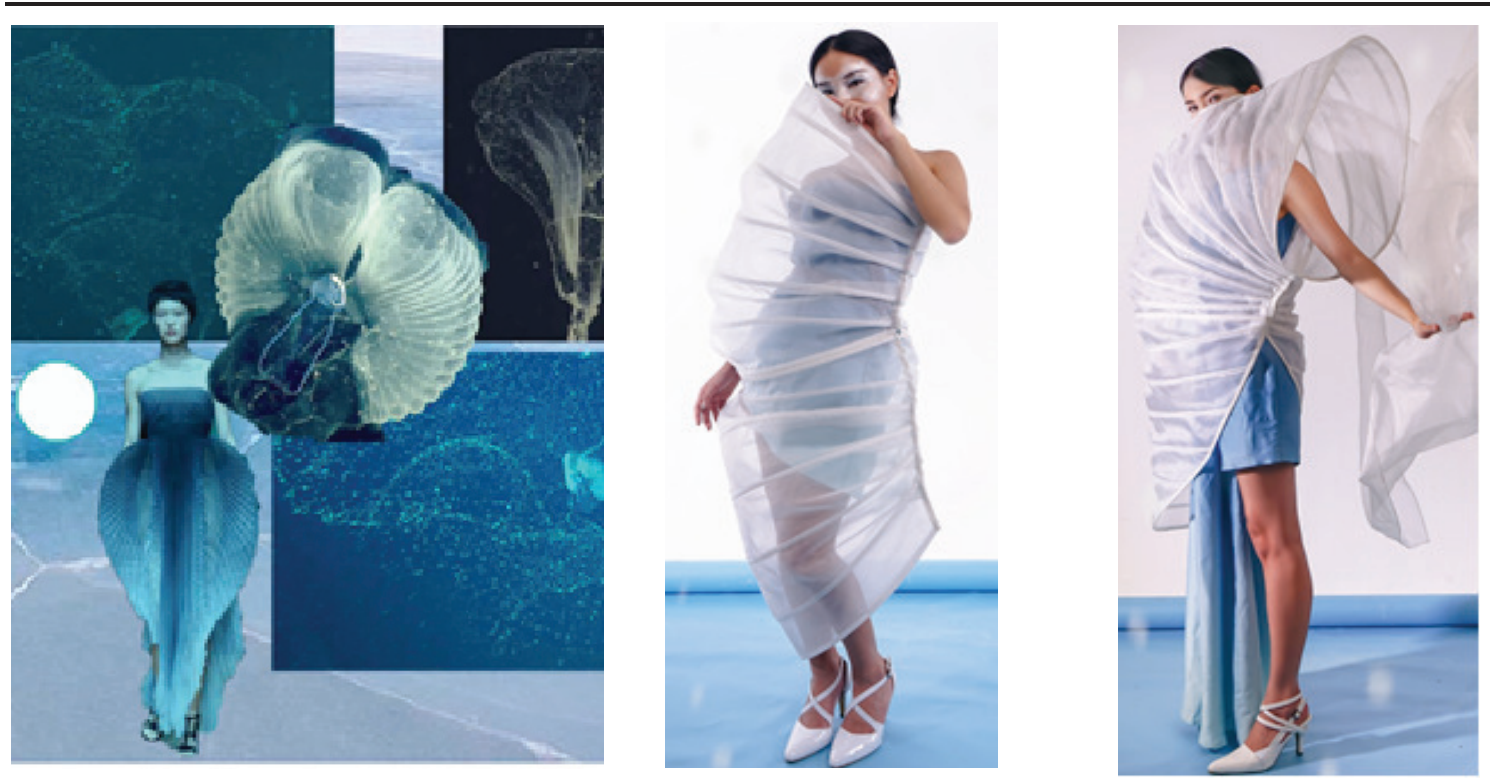

Deskripsi dan analisis:

Busana 'Antrachoda' karya Vallerie Janicia didasarkan pada hasil penelitian tentang larva Giant Larvacean Bathochordeus yang memiliki keunikan untuk mengurangi limbah mikroplastik di dalam laut, sehingga membantu kelestarian ekosistem air laut. Larvacean ini memiliki 2 (dua) bagian outer fibre transparan sebagai rumah sekaligus penyalur limbah plastik dari air laut yang akan dihancurkan oleh inner fibre, kemudian dikonsumsi oleh larva yang terletak di bagian tengah outer fibre. Busana 'Antrachoda' ini sangat inspiratif dan aktual dengan fenomena pencemaran air laut di banyak pantai di Indoneisa yang sangat memprihatinkan akhir-akhir ini. Pencemaran pantai itu antara lain di wilayah-wilayah, seperti Manta Point di Nusa Penida, Kuta di Bali, Pulau Sempu di Malang, Ranu Kumbolo di Lumajang, dan Pulau Tidung di kepulauan Seribu yang menjadi rusak karena tumpukan sampah plastik para wisatawan yang tak bertanggung jaawab. Limbah plastik bukan hanya merusak keindahan pemandangan pantai atau danau, tapi juga berdampak pada kelestarian hidup larva ikan, kerugian di bidang perkapalan, pariwisata, dan pemicu kemiskinan para pelayan serta penduduk pesisir.

Hasil persilangan yang didapat dari studi literatur, studi image, video tentang GiantLarvacean, trend Vigillant subtema Structural dari Trend Grey Zone Forecasting 2017/2018. Fabric manipulation, digital color printing on orcanza fabric, dan arahan dari dosen pembimbing menghasilkan empat kreasi busana semi haute couture yang unik dan inspiratif. Kreasi busana ini menghasilkan temuan yang inovatif, mampu mengkomunikasikan penemuan pengetahuan baru tentang larva laut yangs angat bermanfaat untuk mengurangi limbah plastik, dan relevan dengan fenomena yang sedang dialami oleh masyarakat pesisir. Bentuk dan warna biru tua, biru dan putih transparan diinspirasi dari suasana laut dan bentuk outer fibre Giant Larvacean yang kreatif, unik, dan memukau.

\section{Fesyen Akademik sebagai Cara Kreatif Melawan Gempuran Media}

Pemaparan di atas membuka pertanyaan baru, apakah keberadaan Pendidikan Fesyen Akademik merupakan bentuk lain dari iklan yang mempromosikan gaya hidup yang terus bergulir, sarat dengan bujuk rayu konsumtif? (Wiryanti, 2004:168). Apakah fesyen akademik mampu memberi alternatif untuk melawan, atau setidaknya mengurangi gempuran media?

Masyarakat sebagai segmen pasar cenderung pasif, mengejar gaya hidup dengan memburu menu-menu fesyen up to date agar dapat tampil menawan bak model dalam iklan. Berebut produk-produk baru, menikmati jasa perawatan dari kaki sampai ujung rambut, mengonsumsi suplemen 
Tabel 8. Busana 'Osteodeform' inspirasi dari dampak radiasi nuklir pada mutasi DNA tulang

\begin{tabular}{lll}
\hline Mood Board Tugas Akhir DIII & Look 1 & Look 2 \\
Seni Rupa dan Desain UK Maranatha & Sumber: Oey Bella Setiawan & Sumber: Oey Bella Setiawan \\
2017 karya Oey Bella Setiawan Wijaya & Wijaya & Wijaya \\
\hline
\end{tabular}
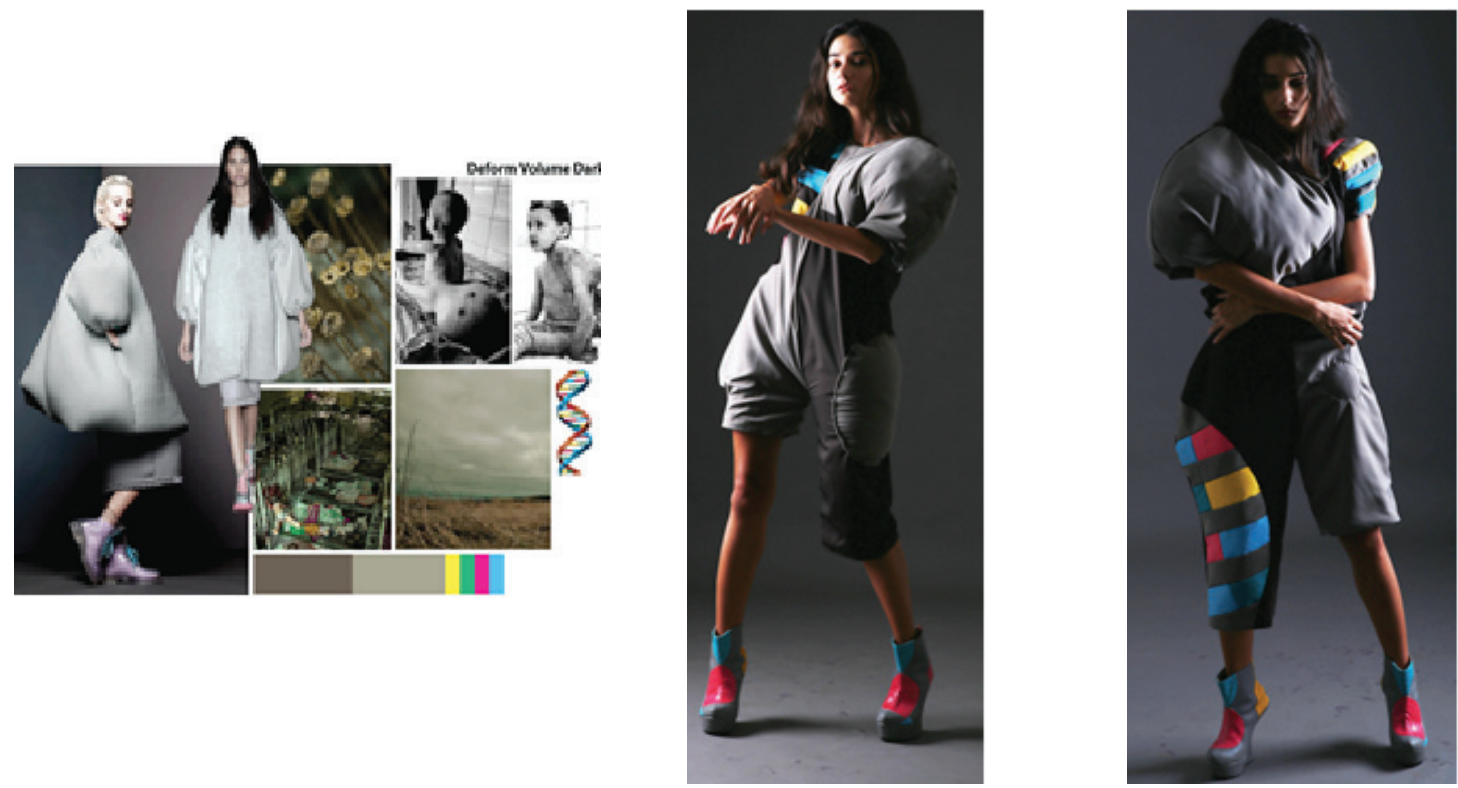

Deskripsi dan analisis:

Busana 'Osteodeform' karya Oey Bella Setiawan Wijaya didasarkan pada hasil penelitian tentang penyakit tumor tulang Osteosarcoma, yaitu jenis tumor tulang yang terjadi akibat radiasi nuklir. Sekarang, penderita penyakit ini cenderung meningkat akibat kebocoran radiasi yang terjadi, baik karena kesengajaan maupun tidak, saat pembuatan maupun saat percobaan hasil pembuatan bom. Akibat dari pencemaran radiasi nuklir adalah terjadinya mutasi pada DNA manusia dan berdampak pada deformasi pertumbuhan tulang pada anak balita yang sifatnya permanen. Semakin banyak tubuh menerima paparan radiasi nuklir, semakin besar pula mutasi DNA dan berakibat pada makin besarnya distorsi bentuk organ tulang. Kreasi busana yang mengangkat isu osteodeform ini merupakan upaya simpati terhadap penderita sekaligus pesan untuk memerangi segala bentuk pengupayaan dan perkembangan bom nuklir di muka bumi.

Hasil persilangan yang didapat dari studi literatur, studi image fisik penderita osteosarcoma, warna DNA manusia, yaitu merah, biru, hijau, merah, dan abu dipadukan dengan tren Archean subtema Bulky dari Grey Zone Forecasting 2017/2018, fabric manipulation, konsep asimetri, dan arahan dari dosen pembimbing menghasilkan empat kreasi busana semi haute couture yang unik dan inspiratif. Kreasi busana ini menghasilkan temuan yang kreatif dan inovatif, mampu mengomunikasikan pesan keprihatinan atas penderita tumor tulang Osteosarcoma akibat dampak radiasi nuklir yang dinilai menghancurkan dan tidak manusiawi.

kecantikan, mengikuti mode fesyen aktual dan bergabung dalam klub kebugaran, akan mengubah konsumen tampil bergaya seperti seorang model.

Dalam situasi ini, apakah pendidikan fesyen akademik mampu menawarkan sisi yang berbeda yang dapat melawan industri fesyen kapitalis yang cenderung menjerumuskan perempuan modern pada selera gaya hidup konsumtif? Berbagai bentuk dan warna diinspirasi dari berbagai isu-isu penting, seper- ti mitologi budaya etnis tertentu, keunikan hewan laut yang ternyata mampu mengurangi limbah plastik, ilusi optik yang dinamis memberi efek visual tiga dimensi dari permainan garis dan bidang hitam putih, ragam hias etnis Sasak Lombok yang menawan dan sarat pesan, kesan nostalgia pada game digital masa awal yang tetap memberi daya tarik, serta kritik terhadap upaya pengadaan bom nuklir yang menghancurkan kelestarian masa depan hidup manusia. 
Tabel 9. Busana 'Pixelvation' inspirasi dari nostaligia game perdana berkarakter pixel

\begin{tabular}{ll}
\hline Mood Board Tugas Akhir DIII & Look 1 dan Look 2 \\
Seni Rupa dan Desain UK Maranatha & Sumber: Liana Japip \\
2017 karya Liana Japip & \\
\hline
\end{tabular}
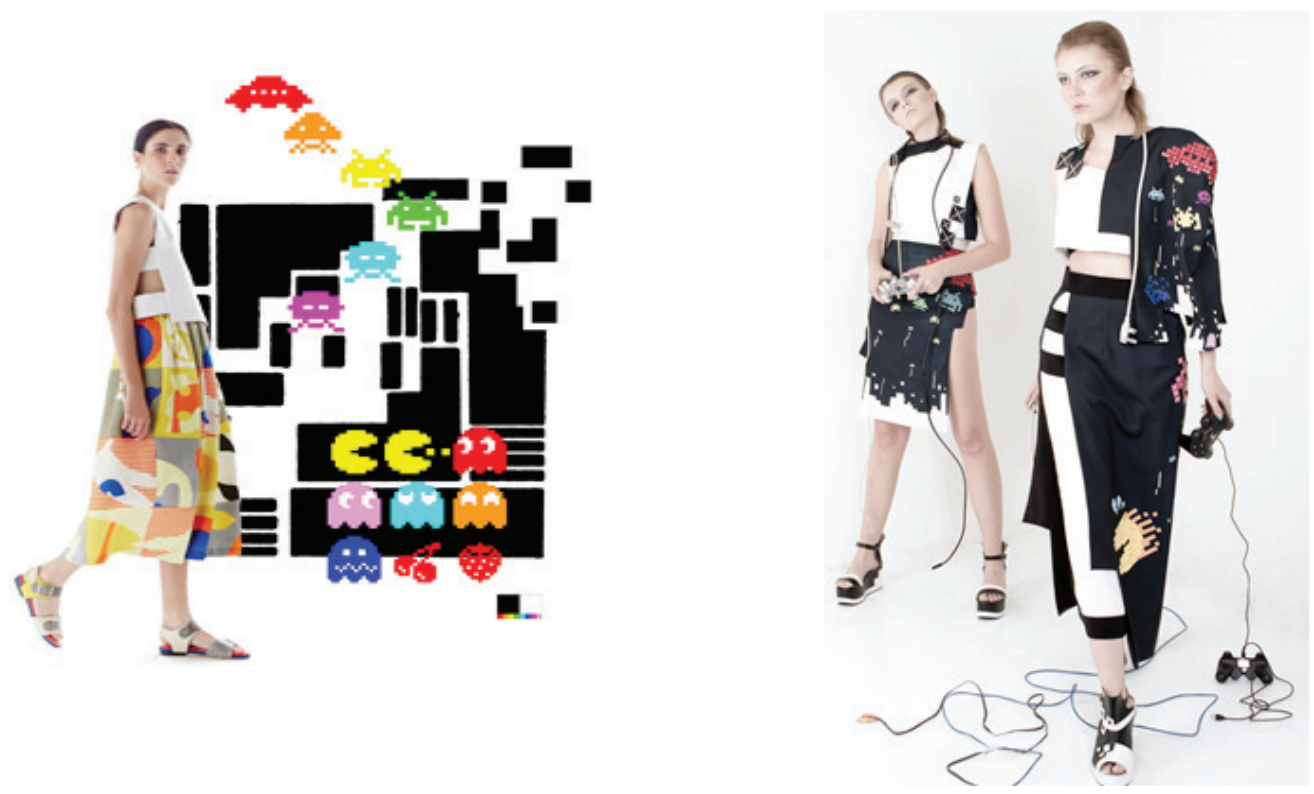

Deskripsi dan analisis:

Busana 'Pixelvation' karya Liana Japip didasarkan pada hasil penelitian tentang Pixel Art (seni tentang visual pixel) yang disimbolisasikan dari game masa awal, yaitu Space invaders dan Pac man, sebelum adanya game yang lebih modern seperti sekarang yang sangat beragam bentuk, teknik, dan visualisasinya. Inspirasi ini dipilih untuk memberi kesan fun dan nilai nostalgia akan capaian teknologi game masa awal yang membangkitkan kenangan dan kerinduan. Bentuk dan warna (dominan latar hitam putih dan warna-warna terang, seperti kuning, hijau, biru, pink, dan ocher menggambarkan para tokoh game). Apakah busana mampu memberi kesan fun dan nilai nostalgia pada gamer? Warna latar belakang hitam putih untuk memberi kesan game masa awal, sebelum ada TV berwarna. Bentuk dan warna hitam, biru tua, biru, merah, kuning, magenta, ocher, hijau, dan putih diinspirasi dari Space invaders dan Pac man.

Hasil persilangan yang didapat dari studi literatur, studi image tentang game masa awal, tren Digitariant subtema Retro feeling dari Trend Grey Zone Forecasting 2017/2018, fabric manipulation berupa laser cutting on taffeta fabric, sulaman cross stitch, konsep asimetri, dan arahan dari dosen pembimbing menghasilkan empat kreasi busana ready to wear yang unik dan inspiratif. Kreasi busana ini menghasilkan temuan yang inovatif, bukan hanya menjadi busana yang fungsional, namun juga kreatif dan cantik, mampu mengomunikasikan kesan nostalgia game masa awal yang masih sederhana yang mungkin akan dilupakan generasi mendatang, dan berupaya melawan budaya fesyen komersial yang kian mengarah ke pemujaan akan tubuh.

Keseluruhan karya mahasisiwa di atas adalah sebagian dari contoh isu kemanusiaan, mitos, seni, budaya, kekayaan alam, dan masih banyak hal lain yang ada di sekeliling hidup manusia yang dapat diangkat dalam tampilan busana. Fesyen memiliki kekuatan menjadi media komunikasi yang komunikatif dan efektif karena kemampuan persuasifnya yang dinamis, menjangkau masyarakat di ruang-ruang publik. Fesyen akademik diharapkan mampu mengisi budaya populer dengan perannya yang berlapis-lapis, bukan hanya menepis budaya konsumtif bujuk rayu media yang dikendalikan dan diformasi kapitalis, namun berpotensi sebagai pemberi inspirasi banyak perempuan untuk menjadi kreatif menghasilkan aspirasi yang inovatif bagi dirinya dan masyarakat luas.

Perbedaan antara fesyen industri kapitalis dibanding fesyen akademik adalah sebagai berikut, 
Tabel 10. Busana 'Koleksi Sasak' inspirasi dari tradisi kain songket etnis Lombok

\begin{tabular}{lll}
\hline Mood Board Tugas Akhir DIII & Look 1 & Look 2 \\
$\begin{array}{l}\text { Seni Rupa dan Desain UK Maranatha } \\
2018 \text { karya Friska Meidina }\end{array}$ & Sumber: Friska Meidina & Sumber: Friska Meidina \\
\hline
\end{tabular}
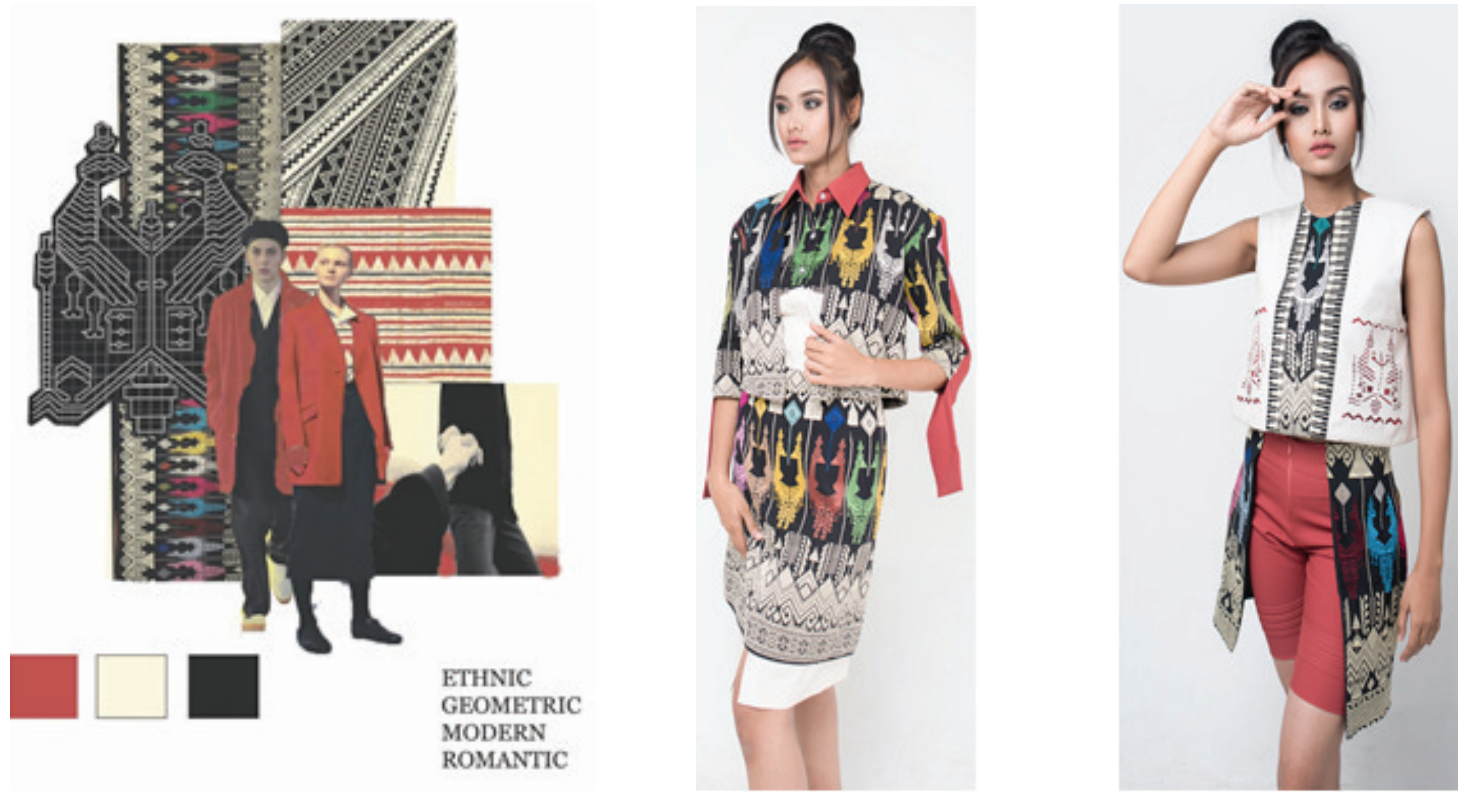

Deskripsi dan analisis:

Busana 'Koleksi Sasak sebagai gaya hidup Urban' karya Friska Meidina didasarkan pada hasil penelitian tentang kain songket tradisional etnis Sasak Lombok, yaitu kain motif Keker. Motif Keker menjelaskan sepasang merak yang sedang memadu kasih di bawah pohon. Motif ini diubah menjadi bentuk geometris akibat dari teknik songket yang tidak memungkinkan membentuk garis lengkung. Keindahan bentuk dan warna burung merak diabadikan dalam bentuk kain songket, yang dihargai masyarakat dan menjadi kepercayaan etnis Sasak karena sifatnya yang sakral. Kain songket motif Sasak memiliki kekuatan mitos tentang kebahagiaan dan kelanggengan yang diyakini masyarakat Lombok sehingga sangat ideal dikenakan oleh calon pengantin.

Hasil persilangan didapat dari studi literatur, studi bentuk dari motif Keker asli kain songket etnis Sasak, dengan tren Vigillant subtema Manual Luxury dari Trend Grey Zone Forecasting 2017/2018. Sedangkan, bentuk geometris merak, warna hitam, biru, merah, hijau, kuning dan putih pada motif keker diinspirasi dari songket Keker. Kreasi busana ini menghasilkan temuan yang inovatif, bukan hanya menjadi busana yang fungsional, namun juga sangat cantik, mampu mengomunikasikan kekayaan dan kearifan budaya tradisi etnis Sasak yang belum banyak dikenal masyarakat, sebuah desain yang inovatif dan berupaya melawan budaya fesyen komersial yang kian mengarah pada pemujaan akan tubuh.

Fesyen Industri Kapitalis:

1. Sasaran iklan dan fashion show adalah meningkatkan segmen pasar,

2. Mendorong dan menciptakan masyarakat konsumtif tanpa henti,

3. Mengejar gaya hidup seperti bintang/ model dalam iklan, bilamana tidak tercapai akan menjadi siksaan mental, tertekan, gagal, dan depresi.

Fesyen Akademik:

1. Temuan penelitian dan hasil kreasi yang ditampilkan lewat pameran, ba- zar, dan fashion show tahunan sebagai upaya untuk meningkatkan apresiasi dan inspirasi,

2. Mendorong dan menciptakan masyarakat kreatif, produktif, dan inovatif,

3. Menciptakan gaya hidup inovatif, dan hasilnya menghargai, menerima serta bangga akan keberadaan dirinya, mampu melihat dan mengembangkan kreativitas dari sisi positif yang lain yang dimiliki walau tak secantik para bintang. 


\section{SIMPULAN}

Fesyen busana sudah menjadi kebutuhan hidup masyarakat, baik perempuan, maupun laki-laki modern, di segala tempat dan waktu. Tampil menarik dan cantik seperti perempuan komersial dalam iklaniklan, telah membius sebagian besar perempuan modern dan menjadi citra yang tanpa sadar terus dikejar. Kecantikan yang bersifat lahiriah ini telah menjadi budaya visual atas strategi kapitalis yang terus 'membu$\mathrm{ru}^{\prime}$ kita di manapun dan kapanpun berada, sehingga selalu ditemukan iklan berwajah komersial. Di sisi lain, fesyen akademik berupaya mengonter kondisi perempuan modern agar tidak terus mengejar budaya populer formasi komersial kapitalis dengan menawarkan ide-ide kreatif dan inovatif.

Promosi yang dilakukan fesyen akademik adalah fesyen hasil penggalian kreatif atas berbagai hal, bahkan mampu menjangkau hal-hal di luar ranah fesyen itu sendiri. Fesyen akademik menjadi media komunikasi yang efektif karena tanda yang dilekatkan pada tubuh yang aktif bergerak mempunyai kekuatan dan peluang untuk mempromosikan pesan-pesan di ruangruang publik. Berbagai temuan pengetahuan, kejadian alam, isu masa depan, nilai sejarah, tradisi, mitos, fenomena ekonomi, sosial, budaya, dan politik dapat diangkat melalui kreativitas fesyen. Melalui sarana pameran, bazar dan fashion show bagi fesyen akademik, penggalian ide dan kreativitas busana kreasi mahasiswa ini dapat menginspirasi perempuan Indonesia untuk melihat sisi positif fesyen akademik.

Pada gilirannya, inspirasi ini mampu mengeliminir pesona gaya hidup fesyen komersial dan menciptakan alternatif yang positif dan kreatif. Fesyen bukan sekedar perburuan gaya hidup konsumtif tanpa akhir, namun fesyen merupakan media komunikasi yang efektif dalam mengisi khasanah budaya popular kita dengan penggalian ide-ide kreatif dan inovatif dalam mentransmisikan pesan dan peran yang berlapis.

\section{Ucapan Terima Kasih}

Terima kasih saya sampaikan kepada Prof. Dr. Yasraf Amir Piliang, MA yang telah memberi masukan yang berharga atas isi penelitian dan kepada Universitas Kristen Maranatha yang telah memberikan fasilitas dan dana hingga penelitian dapat terlaksana dengan baik.

\section{Daftar Pustaka}

Barnard, M. (1996). Fashion as Communication. Diterjemahkan oleh Idi Subandy Ibrahim. 2011. Fesyen sebagai Komunikasi: Cara Mengkomunikasikan Identitas Sosial, Seksual, Kelas, dan Gender.Yogyakarta: Jalasutra.

Baudrillard, J. (1987). The Ecstacy of Communication. New York: Semiotext(e). . (1998). The Consumer: Myths and Structure. London: Sage publication Ltd.

Eco, U. (1976). Travel in Hyper-Reality. Diterjemahkan oleh Iskandar Zulkarnaen. 2004. Tamasya dalam Hiperrealitas. Yogyakarta: Jalasutra.

Ibrahim, I. S. (2011). Budaya Populer sebagai Komunikasi: Dinamika Popscape dan Mediascape di Indonesia Kontemporer. Yogyakarta: Jalasutra.

Indonesia Trend Forecasting. (2014). Re+habitat Trend Forecasting 2015/2016. RaRawamangun: BD+A Design.

Piliang, Y. A. (1993). Memahami Kode-kode Gaya Posmodern. Makalah Ceramah. Balai Pertemuan Ilmiah, ITB, Bandung (29 April).

Yudhistira, D. (2014). Fetisisme Ras Kaukasoid dan Ras Mongoloid sebagai Strategi Pemasaran dalam Sinetron Indonesia. Panggung, 24 (4), 365-375.

Wardhani, A. (2016). Representasi Perempuan Indonesia melalui Artikel Mode pada Majalah Femina. Panggung, 26 (4), 336-350.

Wiryanti B.U. S. (2004). Iklan dan Hiper-realitas Perempuan. Nirmana, 6 (2), 158-170. 